
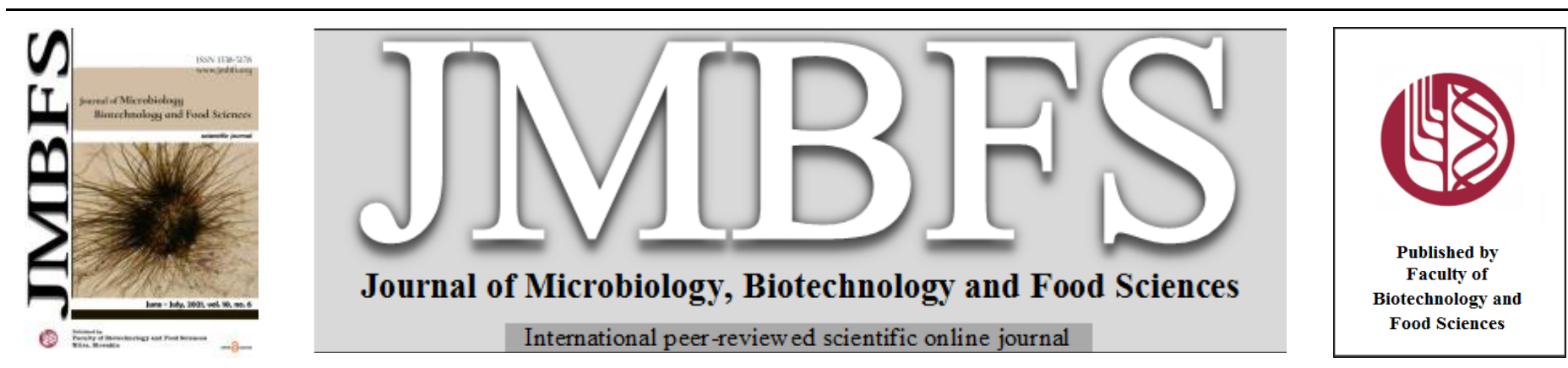

\title{
EFFECT OF Pleurotus ostreatus AQUEOUS EXTRACT ON PHYSICOCHEMICAL PROPERTIES, PROTEIN PROFILE AND TOTAL LACTIC ACID BACTERIA OF YOGURT FORTIFIED WITH Lactobacillus acidophilus
}

\author{
Sjaloom E. Sakul ${ }^{1}$, Djalal Rosyidi* ${ }^{2}$, Lilik Eka Radiati $^{2}$, Purwadi $^{2}$, Herly Evanuarini $^{2}$ \\ Address(es): Prof. Dr. Djalal Rosyidi, \\ ${ }^{1}$ Universitas Brawijaya, Faculty of Animal Science, Postgraduate Program, Jl. Veteran, 65145, Malang, Indonesia. \\ ${ }^{2}$ Universitas Brawijaya, Faculty of Animal Science, J1. Veteran, 65145, Malang, Indonesia, Tel./Fax.: +62-341-553513/+62-341-584727.
}

*Corresponding author: djalal_tht@ub.ac.id

https://doi.org/10.15414/jmbfs.2551

\section{ARTICLE INFO}

Received 17. 1.2020

Revised 4. 1. 2021

Accepted 20. 1. 2021

Published 1. 6. 2021

Regular article

OPEN $\partial_{\text {ACCESS }}$

\begin{abstract}
Syneresis and low viscosity are two major quality defects found in yogurt. The addition of food stabilizer is necessary to overcome the issue. Oyster mushroom (Pleurotus ostreatus) could be utilized as a source of natural food stabilizer because it contains $\beta$-glucan. The objective of this study was to evaluate the effect of Pleurotus ostreatus aqueous extract (POAE) on physicochemical properties, protein profile and total lactic acid bacteria of yogurt fortified with Lactobacillus acidophilus. Yogurt was processed with the addition of POAE at $1 \%, 2 \%$, and $3 \%(\mathrm{v} / \mathrm{v})$ before fermentation and compared with control. Yogurt added with 3\% POAE had the highest viscosity $(\mathrm{P}<0.05)$, protein content $(\mathrm{P}<0.05)$, and total acid content $(\mathrm{P}<0.05)$, but had the lowest syneresis $(\mathrm{P}<0.05)$ among others. The addition of POAE up to $3 \%(\mathrm{v} / \mathrm{v})$, however, did not affect reducing sugar content and total lactic acid bacteria in yogurt. A $12.49 \mathrm{kDa}$ protein was present in yogurt added with 3\% POAE. Therefore, POAE could be used as natural stabilizer for yogurt fortified with Lactobacillus acidophilus with recommended addition level of $3 \%(\mathrm{v} / \mathrm{v})$.
\end{abstract}

Keywords: Probiotic yogurt, oyster mushroom, stabilizer, syneresis, viscosity

\section{INTRODUCTION}

Yogurt is one of dairy products that offers health benefits. Yogurt is fermented by two well-known lactic acid bacteria (LAB), Lactobacillus bulgaricus and Streptococcus thermophilus. The fortification of probiotics such as Bifidobacterium animalis and Lactobacillus acidophilus to yogurt has been reported to make yogurt being categorized as a functional food (Lisko et al., 2017). Probiotics are utilized for balancing gut microbiota and eventually preserves gut health (von Martels et al., 2017). Marchesi et al. (2016) mentioned that manipulating the composition of gut microbiota could potentially reduce the risk of metabolic syndrome, obesity-related disease, liver disease, inflammatory bowel disease and colorectal cancer through the supplementation of probiotics in diet.

Low viscosity and syneresis are two most common problems affecting the quality and acceptance of yogurt. These quality defects are the results of low final $\mathrm{pH}$ of yogurt. Besides uncontrolled fermentation conditions and storage time, the fortification of probiotics to yogurt could affect the acidity level and the $\mathrm{pH}$ of the final products. More organic acids are potentially produced by probiotics strain LAB such as Lactobacillus acidophilus (Sarkar and Misra, 2010). The low $\mathrm{pH}$ condition causes the casein in yogurt losing its water-binding ability, promotes syneresis, degrades the firmness and lowers the acceptance (Sawitri $\boldsymbol{e t}$ al., 2008). In order to avoid quality defects in yogurt caused by low $\mathrm{pH}$ condition, natural food stabilizer should be added (Basiri et al., 2018).

Food stabilizer is commonly made from starch, gelatin and protein concentrate (Clark et al., 2014). Yogurt made with food stabilizer has acceptable viscosity and no syneresis is found during display (Skryplonek et al., 2019). Oyster mushroom (Pleurotus ostreatus) is rich in $\beta$-glucan that can be used as natural food stabilizer (Tjokrokusumo, 2010). $\beta$-glucan is one of dietary fibers that offers health benefits such as immunomodulator, reduce plasma cholesterol, prevent hypertension, diabetes, obesity and colorectal cancer (Lambeau and McRorie, 2017). Lazaridou et al., (2014) reported that $\beta$-glucan extracted from wheat improves viscosity and acceptance, reduces syneresis and calories without altering $\mathrm{pH}$. The utilization of Pleurotus ostreatus has been studied in low-fat yogurt and yogurt drink (Vital et al., 2015; Anissa and Radiati, 2018). However, there is no information regarding the proper addition level of Pleurotus ostreatus in the form of aqueous extract to improve the quality of probiotics yogurt. Therefore, the objective of this study was to evaluate the effect of Pleurotus ostreatus aqueous extract (POAE) on physicochemical properties, protein profile and total lactic acid bacteria of yogurt fortified with Lactobacillus acidophilus.

\section{MATERIALS AND METHODS}

\section{Pleurotus ostreatus aqueous extract preparation}

The mushroom was soaked in water, rinsed and drained. Distilled water was added to mushroom (1:1, weight/weight) and homogenized for $10 \mathrm{~min}$ using food blender with maximum speed. The mushroom aqueous extract was pasteurized at $75^{\circ} \mathrm{C}$ for $30 \mathrm{~min}$, cooled down to $45^{\circ} \mathrm{C}$ and filtered with cheesecloth. Pleurotus ostreatus aqueous extract (POAE) was immediately used for yogurt manufacture.

\section{Yogurt preparation}

Yogurt was made according to a method described by Tamime and Robinson (2014). Briefly, whole milk obtained from Friesian Holstein cow was added with different levels of POAE (\%, volume/volume); $1 \%, 2 \%$ and $3 \%$, pasteurized at $85^{\circ} \mathrm{C}$ for $15 \mathrm{~min}$, cooled down to $45^{\circ} \mathrm{C}$. The milk was inoculated with $3 \%$ (weight/volume of milk) starter culture obtained from laboratory stock cultures, consisting of Lactobacillus bulgaricus, Streptococcus thermophilus, and Lactobacillus acidophilus with a ratio of 1:1:1. Liquid starter culture was diluted in $30 \mathrm{~mL}$ of pasteurized milk, added to the rest of pasteurized milk, and mixed for $10 \mathrm{~min}$. The inoculated milk was incubated at $27^{\circ} \mathrm{C}$ for $18 \mathrm{~h}$. Physicochemical and microbiological analyses were performed immediately after incubation.

\section{Viscosity, total acid content, syneresis and $\mathrm{pH}$ measurement}

Yogurt viscosity was measured using Brooke Field viscometer (AMTEK Brookfield, Middleboro, MA) with spindle No. 6 at $20 \mathrm{rpm}$. Yogurt was stirred for $5 \mathrm{~min}$ at room temperature $\left(25 \pm 1^{\circ} \mathrm{C}\right)$. Viscosity (cP) was calculated as measurement unit shown in viscometer multiplied with 1000. Total acid content equivalent with lactic acid content was determined by titrating $20 \mathrm{~mL}$ of the samples (added with 2 drops of $1 \%$ phenolphthalein) with $0.1 \mathrm{~N} \mathrm{NaOH}$ until the color changes into pink. Total acid content (\%) was calculated according to AOAC method (AOAC, 2005). Syneresis was determined using centrifugation method (Robitaille et al., 2009). Yogurt was weighed in a centrifuge tube and centrifuged at $1535 \mathrm{rpm}$ for $20 \mathrm{~min}$. The supernatant (whey released) was 
weighed and syneresis was calculated as the weight percentage of whey released. The $\mathrm{pH}$ of the sample was determined in duplicate using a calibrated $\mathrm{pH}$ meter.

\section{Protein and reducing sugar content measurement}

Yogurt protein content was measured using Kjeldahl method (AOAC, 2005) Crude protein was calculated as nitrogen content multiplied by 6.25 . Reducing sugar content was determined using Luff-Schoorl reactant (Marrubini et al., 2017)

\section{Lactic acid bacteria measurement}

The number of lactic acid bacteria (LAB) was estimated by plating on MRS agar media. Plates were incubated at $30^{\circ} \mathrm{C}$ for $48 \mathrm{~h}$, under anaerobic conditions. Total lactic acid bacteria were counted and expressed as $\log \mathrm{CFU} / \mathrm{mL}$.

\section{Protein profiling}

Protein profile of the yogurt was identified based on their molecular weight using gel electrophoresis method (Pisanu et al., 2011). Sodium dodecyl sulfatepolyacrylamide gel electrophoresis (SDS-PAGE) was performed using a $15 \%$ polyacrylamide gel containing $30 \%$ acrylamide solution, $1.0 \mathrm{M}$ Tris- $\mathrm{HCl}(\mathrm{pH}$ 8.8), $10 \%$ SDS, $10 \%$ ammonium persulfate, and 10\% N,N,N',N'-tetramethylethylenediamine. The digesta sample was mixed with the same volume of sample buffer composed of $125 \mathrm{mM}$ Tris- $\mathrm{HCl}(\mathrm{pH} 6.8), 2 \%$ glycerol, $2 \%$ SDS, $2 \%$ mercaptoethanol, and $0.02 \%$ bromophenol blue, and heated at $95^{\circ} \mathrm{C}$ on a heating block for $90 \mathrm{sec}$. The $10 \mu \mathrm{L}(74.7 \mu \mathrm{g}$ protein) of a sample and the $5 \mu \mathrm{L}$ of protein molecular markers $(9-200 \mathrm{kDa})$ were loaded. Electrophoretic separation was performed with the pageRun system (AE-6531 mPAGE, ATTO Co., Tokyo, Japan) by applying $20 \mathrm{~mA}$ for $120 \mathrm{~min}$. The running buffer was composed of 25 $\mathrm{mM}$ Tris, $0.1 \%$ SDS, and $192 \mathrm{mM}$ glycine. Proteins in the gels were stained with Coomassie Brilliant Blue and then destained in a $10 \%$ acetic acid solution. Serum albumin $(66.2 \mathrm{kDa})$, ovalbumin $(45.0 \mathrm{kDa})$, carbonic anhydrase $(31.0 \mathrm{kDa})$ dan lysozyme $(14.0 \mathrm{kDa})$ were used as marker. The stained gel was scanned using a GS-710 (Bio-Rad Laboratories Inc, Hercules, CA, USA) densitometer at an optical resolution of $63.5 \mu \mathrm{m}$ pixel-1.

\section{Statistical analysis}

This study employed a completely randomized design. The effect of POAE addition level $(1 \%, 2 \%$, and $3 \%$, v/v) on physicochemical and total lactic acid bacteria of yogurt was observed using one-way analysis of variance. When significant, mean differences $(\mathrm{p}<0.05)$ were determined using least significant different test (Subali, 2010)

\section{RESULTS AND DISCUSSION}

\section{Physical properties}

Analysis variance revealed that the viscosity, total acid content and syneresis of yogurt added with POAE at different level were significantly different $(\mathrm{P}<0.05)$ The mean differences among treatments and control are shown in Table 1. However, the $\mathrm{pH}$ of control and treatments were not significantly different.

Table 1 Viscosity, total acid content and syneresis of yogurt added with different levels of Pleurotus ostreatus aqueous extract

\begin{tabular}{lcccc}
\hline \multirow{2}{*}{ Variable } & \multicolumn{4}{c}{ The addition level of Pleurotus ostreatus aqueous extract } \\
\cline { 2 - 5 } & $0 \%$ & $1 \%$ & $2 \%$ & $3 \%$ \\
\hline Viscosity (cP) & $613.25 \pm 45.56^{\mathrm{a}}$ & $685.50 \pm 27.14^{\mathrm{b}}$ & $756.50 \pm 32.18^{\mathrm{c}}$ & $864.75 \pm 20.90^{\mathrm{d}}$ \\
Total acid content (\%) & $0.68 \pm 0.03^{\mathrm{a}}$ & $0.72 \pm 0.04^{\mathrm{a}}$ & $0.69 \pm 0.02^{\mathrm{a}}$ & $0.78 \pm 0.03^{\mathrm{b}}$ \\
Syneresis (\%) & $56.77 \pm 0.96^{\mathrm{c}}$ & $54.44 \pm 1.28^{\mathrm{bc}}$ & $53.55 \pm 1.33^{\mathrm{ab}}$ & $52.33 \pm 2.53^{\mathrm{a}}$ \\
$\mathrm{pH}$ & $4.09 \pm 0.03$ & $4.11 \pm 0.11$ & $4.08 \pm 0.10$ & $4.01 \pm 0.07$ \\
\hline Lend $^{\text {a d }}$ Means with different supersipts
\end{tabular}

Viscosity is one of physical properties of most of liquid or semi-solid food, including yogurt that is responsible for consumer acceptance. The addition of POAE gave an effect on viscosity, in which the higher the addition level was, the higher the viscosity of yogurt was observed. The viscosity values of yogurt found in treatment groups were in the normal range set by national standard (BSN 2009). The national standard for the acceptable viscosity of yogurt ranges from 670 to $890 \mathrm{cP}$. The viscosity of the control, however, could not meet national standard. The viscosity of high-quality yogurt is between semi-solid and liquid. This is affected by the coagulation of water-binding protein in yogurt. Wang $\boldsymbol{e}$ al. (2018) mentioned that milk protein coagulation is caused by enzymatic reactions. The enzymes are derived from the metabolism of microorganism found in milk. In case of yogurt, Streptococcus thermophilus and Lactobacillus bulgaricus are responsible for protein coagulation. These LAB utilize lactose as carbon and energy sources during fermentation, producing metabolites such as lactic acid. Lactic acid decreases the $\mathrm{pH}$ of milk until reaching isoelectric point the condition where protein coagulates. The acid condition triggers the separation of $\beta-, \alpha-, \kappa-, \alpha s 1-, \alpha s 2$-casein and eventually causes the coagulation of casein (Burton, 2014). Widyastuti et al. (2011) reported that the viscosity of POAE ranged from 11 to $19.70 \mathrm{cP}$. Therefore, POAE could improve the viscosity of yogurt (Tamime and Robinson, 2014).

Yogurt has sour taste as it contains lactic acid that is produced by LAB during fermentation. According to national standard, the acceptable range of total acid content of yogurt is from 0.5 to $2.0 \%$ (BSN, 2009). The total acid content $(0.68 \%-0.78 \%)$ of yogurt found in this study met the national standard. Yogurt added with $3 \%$ POAE had the highest total acid content $(\mathrm{P}<0.05)$. POAE could be utilized by LAB as additional carbon source as POAE contains $\beta$-glucan, a water-soluble dietary fiber and a prebiotic (Sari et al., 2017; Lam et al., 2019). This could increase the production of acid by LAB, thus the total acid content of yogurt added with $3 \%$ POAE was higher than the others.

Syneresis is one of quality defects found in yogurt. The $\mathrm{pH}$, total acid content and water-holding capacity influence the occurrence of syneresis in yogurt (Dönme et al., 2017). The addition of POAE to the yogurt reduced syneresis susceptibility. Yogurt added with 3\% POAE had the lowest syneresis $(\mathrm{P}<0.05)$ In this study, POAE was found to possess the functional characteristics of food stabilizer as POAE was responsible to increase viscosity and reduce syneresis. PO has been well known containing $\beta$-glucan (Sari et al., 2017). This watersoluble dietary fiber has been observed having water-binding properties and improving the rheological characteristics of full fat yogurt (Kaur and Riar, 2020)

POAE plays a role as energy source for $\mathrm{LAB}$ to grow and the metabolites such as lactic acid decrease the $\mathrm{pH}$ of yogurt. Syainah et al. (2014) mentioned that the higher the total lactic acid bacteria present in yogurt, the lower the $\mathrm{pH}$ and the higher the acidity level are observed. Akiyama et al. (2019) reported that $\mathrm{pH}$ value is negatively associated with total acid content of yogurt. In this study, there were no significant differences found on $\mathrm{pH}$ value of the yogurt. The observed $\mathrm{pH}$ value ranged from 4.01 to 4.11 (lower than casein isoelectric point) Francis et al. (2019) mentioned that the isoelectric point of the casein ranges from $\mathrm{pH} 4.3$ to $\mathrm{pH}$ 4.7. The fortification of probiotics to yogurt in this study could lower the $\mathrm{pH}$ value of the final products. More organic acids are potentially produced by Lactobacillus acidophilus (Sarkar and Misra, 2010).

\section{Protein and reducing sugar content}

Table 2 shows that the protein content of yogurt added with POAE at different level was significantly different $(\mathrm{P}<0.05)$. The protein content of yogurt depends on the quality of the milk or protein content of skim milk. According to national standard, acceptable yogurt should contain at least $2.7 \%$ of protein $(\mathbf{B S N}, 2009)$ In this study, the addition of POAE positively impacted the protein content of the yogurt as the protein content of POAE contributed to the additional amount of protein in yogurt. POAE in this study contained $31.02 \pm 0.92$ of protein (data are not shown).

Table 2 Protein and reducing sugar content of yogurt added with different levels of Pleurotus ostreatus aqueous extract

\begin{tabular}{lcccc}
\hline Variable & \multicolumn{4}{c}{ The addition level of Pleurotus ostreatus aqueous extract } \\
\cline { 2 - 5 } & $0 \%$ & $1 \%$ & $2 \%$ & $3 \%$ \\
\hline Protein (\%) & $2.63 \pm 0.01^{\mathrm{a}}$ & $2.73 \pm 0.01^{\mathrm{b}}$ & $2.79 \pm 0.00^{\mathrm{c}}$ & $2.92 \pm 0.01^{\mathrm{d}}$ \\
Reducing sugar (\%) & $4.91 \pm 0.29$ & $5.55 \pm 1.08$ & $5.56 \pm 1.08$ & $6.33 \pm 0.76$ \\
\hline Legend: ${ }^{\mathrm{a} \sim \mathrm{d}}$ Means with different superscripts were significantly different $(\mathrm{P}<0.05)$ & &
\end{tabular}

No significant differences were observed on reducing sugar content in yogurt added with POAE. High reducing sugar content in yogurt added with POAE was caused by the carbohydrate present in POAE. Umi et al. (2013) mentioned that
$25 \%-30 \%$ of monosaccharides in milk are hydrolyzed by LAB during fermentation. Lactose in milk is not easily digested in human intestine, however, it can be digested by gut LAB (Forsgård, 2019). LAB produces $\beta-D$ 
galaktosidase to hydrolize lactose and anaerobic glycolysis results in lactic acid, acetic acid and some other volatile organic acids (Hidayat $\boldsymbol{e t}$ al., 2013). Thus, yogurt is more likely suitable for those who have lactose-intolerant.

\section{Total lactic acid bacteria}

Table 3 shows that total LAB in yogurt added with POAE at different level was not different significantly. The viability of LAB in yogurt is shown by the number of these bacteria, $\mathrm{pH}$, lactose content and total acid content (Syainah $\boldsymbol{e t}$ al., 2014). The acceptable range of total LAB in yogurt is $7 \log C F U / m L$ (BSN, 2009). The addition of POAE contributed to the viability of LAB as POAE could be used as carbon and energy sources. $\beta$-glucan derived from POAE is a prebiotic that supports the viability of LAB in yogurt. Therefore, total LAB in treatment groups was within the standard range.

Table 3 Total lactic acid bacteria in yogurt added with different levels of Pleurotus ostreatus aqueous extract

\begin{tabular}{lc}
$\begin{array}{l}\text { The addition level of Pleurotus ostreatus } \\
\text { aqueous extract }\end{array}$ & $\begin{array}{c}\text { Total lactic acid bacteria } \\
(\log \text { CFU/mL) }\end{array}$ \\
\hline $0 \%$ & $6.85 \pm 0.10$ \\
$1 \%$ & $6.86 \pm 0.21$ \\
$2 \%$ & $7.02 \pm 0.07$ \\
$3 \%$ & $7.06 \pm 0.07$ \\
\hline
\end{tabular}

\section{Protein profile}

SDS-PAGE revealed protein bands derived from yogurt added with POAE (Figure 1). There were six fractions with different molecular weights found in all groups except for yogurt added with 3\% POAE. The highest addition level (3\%) resulted in the presence of fraction with molecular weight of $12.49 \mathrm{kDa}$. The other six fractions' weight ranged from $10.41 \mathrm{kDa}$ to $146.49 \mathrm{kDa}$ (Table 4). Karitas and Fatchiyah (2013) mentioned that the molecular weight of $\alpha$-casein, $\beta$-casein and $\kappa$-casein ranged from 30 to $60 \mathrm{kDa}$. Susanti and Hidayat (2016) mentioned that bacterial fermentation is responsible for the degradation of macro molecules in food into novel micro molecules. The presence of observed fractions figures out the degradation of milk major protein during fermentation. Furthermore, the addition of POAE at $3 \%(\mathrm{v} / \mathrm{v})$ to yogurt resulted in the presence of unique fraction with molecular weight of $12.49 \mathrm{kDa}$

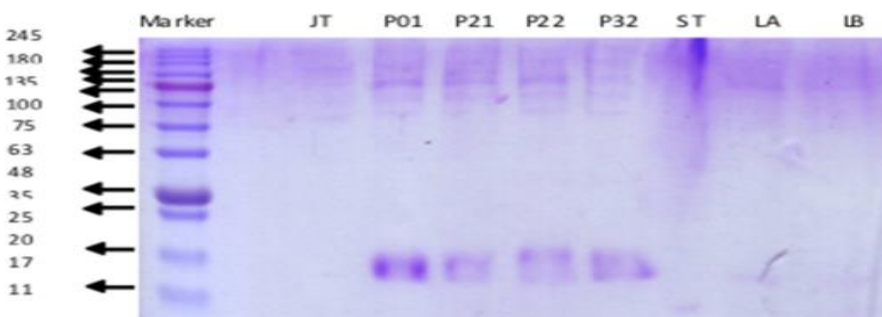

Figure 1 SDS PAGE gel showing protein derived from yogurt added with different levels of Pleurotus ostreatus aqueous extract (POAE). JT: Pleurotus ostreatus aqueous extract, P01: Control, P12: Yogurt + 1\% POAE, P22: yogurt + 2\% POAE, P32: Yogurt + 3\% POAE, Streptococcus thermophilus (ST), Lactobacillus acidophilus (LA), Lactobacillus bulgaricus (LB).

Table 4 Molecular weight of protein derived from yogurt added with different levels of Pleurotus ostreatus aqueous extract

\begin{tabular}{lcccc}
\hline \multirow{2}{*}{ No. } & \multicolumn{4}{c}{ Molecular weight (kDa) } \\
\cline { 2 - 5 } & $0 \%$ & $1 \%$ & $2 \%$ & $3 \%$ \\
\cline { 2 - 5 } & 146.49 & 146.49 & 146.49 & 146.49 \\
2 & 122.07 & 122.07 & 122.07 & 122.07 \\
3 & 101.72 & 101.72 & 101.72 & 101.72 \\
4 & 84.76 & 84.76 & 84.76 & 84.76 \\
5 & 64.48 & 64.48 & 64.48 & 64.48 \\
6 & 10.41 & 10.41 & 10.41 & 12.49 \\
7 & - & - & - & 10.41 \\
\hline
\end{tabular}

\section{CONCLUSION}

Pleurotus ostreatus aqueous extract can be utilized as stabilizer to improve viscosity and reduce syneresis of yogurt fortified with Lactobacillus acidophilus The addition level of POAE at 3\% (volume/volume) is recommended.
Acknowledgments: The authors would like to thank Directorate General of Higher Education of the Republic of Indonesia (DIKTI) for Beasiswa Pendidikan Pascasarjana Dalam Negeri (BPPDN).

\section{REFERENCES}

Akiyama, K., Horita, K., Sakamoto, T., Satozono, H., Takahashi, H., \& Goda, Y. (2019). Monitoring the progress of lactic acid fermentation in yogurt manufacturing using terahertz time-domain-attenuated total-reflection spectroscopy. Journal of Infrared Millimeter, and Terahertz Waves, 40, 1160 1167. https://doi:10.1007/s10762-019-00642-9

Anissa, D., \& Radiati, L. E. (2018). Effect of the addition of white oyster mushroom (Pleurotus ostreatus) extract on the manufacture of yogurt drink in terms of physical quality. Jurnal Ilmu dan Teknologi Hasil Ternak 13(2), 118 1125. https://doi.org/10.21776/ub.jitek.2018.013.02.6

AOAC. (2005). Analysis of Official Analytical Chemistry Methods. 18th. Ed Washington DC: AOAC International.

Badan Standardisasi Nasional (BSN). (2009). Standar Nasional Indonesia (SNI) 2981:2009 Yogurt. Jakarta: Badan Standardisasi Nasional.

Basiri, S., Haidary, N., Shekarforoush, S. S., \& Niakousari, M. (2018). Flaxseed mucilage: A natural stabilizer in stirred yogurt. Carbohydrate Polymers, 187, 59 65. https://doi.org/10.1016/i.carbpol.2018.01.049

Burton, E., Arief, I. I., \& Taufik, E. (2014). Functional properties of carbonated probiotic yogurt. Jurnal Ilmu Produksi dan Teknologi Hasil Peternakan, 2(1), 213-218. https://doi.org/10.29244/jipthp.2.1.213-218

Clark, S., Jung, S., \& Lamsal, B. (2014). Food Processing: Principle and Application. West Sussex: John Wiley and Sons.

Dönmez, Ö., Mogol, B. A., \& Gökmen, V. (2017). Syneresis and rheological behaviors of set yogurt containing green tea and green coffee powders. Journal of Dairy Science, 100(2), 901-907. https://doi.org/10.3168/jds.2016-11262

Forsgård, R. A. (2019). Lactose digestion in humans: intestinal lactase appears to be constitutive whereas the colonic microbiome is adaptable, The American Journal of Clinical Nutrition, 110(2), 273-279. https://doi.org/10.1093/ajen/nqz104

Francis, M. J., Glover, Z. J., Yu, Q., Povey, M. J., \& Holmes, M. J. (2019) Acoustic characterisation of $\mathrm{pH}$ dependant reversible micellar casein aggregation. Colloids and Surfaces A: Physicochemical and Engineering Aspects, 568(5), 259-265. https://doi.org/10.1016/j.colsurfa.2019.02.026

Hidayat, I. R., Kusrahayu, K., \& Mulyani, S. (2013). Total bakteri asam laktat nilai $\mathrm{pH}$ dan sifat organoleptik drink yoghurt dari susu sapi yang diperkaya dengan ekstrak buah mangga. Animal Agriculture Journal, 2(1), 60-67.

Karitas, M. U., \& Fatchiyah, F. (2013). Profil protein yogurt susu kambing PE dengan kultur tunggal pada 30-60 kDa dengan SDS-PAGE. Biotropika: Journal of Tropical Biology, 1(2), 65-69.

Kaur, R., \& Riar, C. S. (2020). Sensory, rheological and chemical characteristics during storage of set type full fat yoghurt fortified with barley $\beta$-glucan. Journal of Food Science and Technology, 57(1), 41-51. https://doi.org/10.1007/s13197019-04027-7

Lam, K. L., Ko, K. C., Li, X., Ke, X., Cheng, W. Y., Chen, T., You, L., Kwan, H S., \& Cheung, P. C. K. (2019). In vitro infant faecal fermentation of low viscosity barley $\beta$-glucan and its acid hydrolyzed derivatives: evaluation of their potential as novel prebiotics. Molecules, 24(5), 828 . https://doi.org/10.3390/molecules24050828

Lambeau, K. V., \& McRorie Jr, J. W. (2017). Fiber supplements and clinically proven health benefits: How to recognize and recommend an effective fiber therapy. Journal of the American Association of Nurse Practitioners, 29(4), 216 223. https://doi.org/10.1002/2327-6924.12447

Lazaridou, A., Serafeimidou, A., Biliaderis, C. G., Moschakis, T., \& Tzanetakis, N. (2014). Structure development and acidification kinetics in fermented milk containing oat $\beta$-glucan, a yogurt culture and a probiotic strain. Food Hydrocolloids, 39, 204-214. https://doi.org/10.1016/j.foodhyd.2014.01.015

Lisko, D. J., Johnston, G. P., \& Johnston, C. G. (2017). Effects of dietary yogurt on the healthy human gastrointestinal (GI) microbiome. Microorganisms, 5(1), 6 https://doi.org/10.3390/microorganisms5010006

Marchesi, J. R., Adams, D. H., Fava, F., Hermes, G. D. A., Hirschfield, G. M. Hold, G., Quraishi, M. N., Kinross, J., Smidt, H., Tuohy, K. M., Thomas, L. V. Zoetendal, E. G., \& Hart, A. (2016). The gut microbiota and host health: a new clinical frontier. Gut, 65, 330-339. http://dx.doi.org/10.1136/gutjnl-2015-309990 Marrubini, G., Papetti, A., Genorini, E., \& Ulrici, A. (2017). Determination of the sugar content in commercial plant milks by near infrared spectroscopy and LuffSchoorl total glucose titration. Food Analytical Methods, 10(5), 1556-1567. https://doi.org/10.1007/s12161-016-0713-1

Pisanu, S., Ghisaura, S., Pagnozzi, D., Biosa, G., Tanca, A., Roggio, T., ... \& Addis, M. F. (2011). The sheep milk fat globule membrane proteome. Journal of Proteomics, 74(3), 350-358. https://doi.org/10.1016/j.jprot.2010.11.011

Robitaille, G., Tremblay, A., Moineau, S., St-Gelais, D., Vadeboncoeur, C., \& Britten, M. (2009). Fat-free yogurt made using a galactose-positive exopolysaccharide-producing recombinant strain of Streptococcus thermophilus. Journal of Dairy Science, 92(2), 477-482. https://doi.org/10.3168/jds.2008-1312 
Sari, M., Prange, A., Lelley, J. I., \& Hambitzer, R. (2017). Screening of betaglucan contents in commercially cultivated and wild growing mushrooms. Food Chemistry, 216, 45-51. https://doi.org/10.1016/j.foodchem.2016.08.010

Sarkar, S., \& Misra, A. K. (2010). Technological and dietetic characteristics of probiotic acidophilus milk. British Food Journal, 112(3), 275-284. https://doi.org/10.1108/00070701011029147

Sawitri, M. E., Manab, A., \& Palupi, T. W. L. (2008). Kajian penambahan gelatin terhadap keasaman, $\mathrm{pH}$, daya ikat air dan sineresis yogurt. Jurnal Ilmu dan Teknologi Hasil Ternak, 3(1), 35-42.

Skryplonek, K., Henriques, M., Gomes, D., Viegas, J., Fonseca, C., Pereira, C., Dmytrów, I., \& Mituniewicz-Małek, A. (2019). Characteristics of lactose-free frozen yogurt with $\kappa$-carrageenan and corn starch as stabilizers. Journal of Dairy Science, 102(9), 7838-7848. https://doi.org/10.3168/jds.2019-16556

Subali, B. (2010). Analisis Statistika Menggunakan Program SPSS Aplikasinya dalam Rancangan Percobaan. Yogyakarta: Jurusan Pendidikan Biologi, Fakultas MIPA, Universitas Negeri Yogyakarta.

Susanti, R., \& Hidayat, E. (2016). Profil protein susu dan produk olahannya. Jurnal MIPA, 39(2), 98-106.

Syainah, E., Novita, S., \& Yanti, R. (2014). Kajian pembuatan yogurt dari berbagai jenis susu dan inkubasi yang berbeda terhadap mutu dan daya terima. Jurnal Skala Kesehatan, 5, 156-162.

Tamime, A. Y., \& Robinson, R. K. (2014). Yoghurt Science and Technology. Oxford: Pergamon Press Ltd.

Tjokrokusumo, D. (2010). Jamur tiram (Pleurotus ostreatus) untuk meningkatkan ketahanan pangan dan rehabilitasi lingkungan. Jurnal Rekayasa Lingkungan, 4, 53-62.

Umi, F., Prasetyo, F. I., Supia, M., Utami, A. N. (2013). Karakteristik Yogurt Yang Terbuat Dari Berbagai Jenis Susu Dengan Penambahan Kultur Campuran. Jurnal Bioedukasi, 6, 1-9.

Vital, A. C. P., Goto, P. A., Hanai, L. N., Gomes-da-Costa, S. M., de Abreu Filho, B. A., Nakamura, C. V., \& Matumoto-Pintro, P. T. (2015). Microbiological, functional and rheological properties of low fat yogurt supplemented with Pleurotus ostreatus aqueous extract. LWT-Food Science and Technology, 64(2), 1028-1035. https://doi.org/10.1016/j.lwt.2015.07.003

von Martels, J. Z., Sadabad, M. S., Bourgonje, A. R., Blokzijl, T., Dijkstra, G. Faber, K. N., \& Harmsen, H. J. (2017). The role of gut microbiota in health and disease: in vitro modeling of host-microbe interactions at the aerobe-anaerobe interphase of the human gut. Anaerobe, 44, 3-12. https://doi.org/10.1016/j.anaerobe.2017.01.001

Wang, X., Ye, A., Lin, Q., Han, J., \& Singh, H. (2018). Gastric digestion of milk protein ingredients: Study using an in vitro dynamic model. Journal of Dairy Science, 101(8), 6842-6852. https://doi.org/10.3168/jds.2017-14284

Widyastuti, N., Baruji, T., Giarni, R., Isnawan, H., Wahyudi, P., \& Donowati, D. (2011). Analisa kandungan betaglukan larut air dan larut alkali dari tubuh buah jamur tiram (Pleurotus ostreatus) dan shiitake (Lentinus edodes). Jurnal Sains dan Teknologi Indonesia, 13, 182-191. 